\title{
Traditional medicinal plants in South Tyrol (northern Italy, southern Alps): biodiversity and use
}

\author{
Joshua Petelka', Barbara Plagg ${ }^{2,3}$, Ina Säumel ${ }^{4^{*}}$ (D) and Stefan Zerbe ${ }^{1}$
}

\begin{abstract}
Background: Worldwide mountain regions are recognized as hotspots of ethnopharmacologically relevant species diversity. In South Tyrol (Southern Alps, Italy), and due to the region's high plant diversity and isolated population, a unique traditional botanical knowledge of medicinal plants has flourished, which traces its history back to prehistoric times. However, changes in rural life and culture may threaten this unique biodiversity and cultural heritage. Our study aims to collect and analyze information on native plants used in traditional folk medicine, focusing on the preservation of botanical and cultural diversity.

Methods: Data were collected through a review of published material that documents traditionally used medicinal plants of South Tyrol in order to capture the total diversity of plants and their usage. We evaluated different parameters, comprising the ethnobotanicity index (EI), ethnophytonomic index (EPI), relative frequency of citation $(\mathrm{RFC})$, red list status, and regional legislation with regard to the plant species.

Results: A total of 276 species, including 3 mushrooms and 3 lichens, were identified. These belonged to 72 families, most frequently to the Asteraceae, Rosaceae, and Lamiaceae. The most frequently cited species were Hypericum perforatum L., Urtica dioica L., and Plantago lanceolata L. According to 12 ICPC-2 disease categories, the most frequently treated human health symptoms were from the digestive and respiratory systems as well as the skin. A total of 27 species were listed as endangered, of which 16 are not protected and two are now already extinct. Among the 59 predominantly alpine species, 11 species are restricted to the high altitudes of the Alps and may be threatened by global warming.

Conclusions: Our research revealed that the ethnobotanical richness of South Tyrol is among the highest in Italy and throughout the Alps. Nevertheless, it is evident that biodiversity and traditional knowledge have been heavily eroded. Furthermore, we point out particularly sensitive species that should be reconsidered for stronger protections in legal regulations.
\end{abstract}

Keywords: Ecosystem restoration, Human health, Nature conservation, Traditional ecological knowledge, Traditional medicine

\footnotetext{
* Correspondence: ina.saeumel@hu-berlin.de

${ }^{4}$ Integrative Research Institute on Transformations of Human-Environment Systems (IRITHESys), Humboldt Universität zu Berlin, Berlin, Germany Full list of author information is available at the end of the article
}

(c) The Author(s). 2020 Open Access This article is licensed under a Creative Commons Attribution 4.0 International License, which permits use, sharing, adaptation, distribution and reproduction in any medium or format, as long as you give appropriate credit to the original author(s) and the source, provide a link to the Creative Commons licence, and indicate if changes were made. The images or other third party material in this article are included in the article's Creative Commons licence, unless indicated otherwise in a credit line to the material. If material is not included in the article's Creative Commons licence and your intended use is not permitted by statutory regulation or exceeds the permitted use, you will need to obtain permission directly from the copyright holder. To view a copy of this licence, visit http://creativecommons.org/licenses/by/4.0/ The Creative Commons Public Domain Dedication waiver (http://creativecommons.org/publicdomain/zero/1.0/) applies to the data made available in this article, unless otherwise stated in a credit line to the data. 


\section{Introduction}

Worldwide mountain regions are recognized as hotspots of ethnobotanical diversity with a high ethnopharmacological importance (e.g., [1-3]). Local species diversity and the historic isolation of mountain settlements lead to a unique ethnopharmacological knowledge that supports health care of local communities [4, 5]. Biodiversity has always been of outmost importance for the provision and new discovery of medical substances [6]. However, an alarming loss of biodiversity is occurring, particularly in mountain regions as they are disproportionably vulnerable to land-use change $[7,8]$ and climate change $[2,9,10]$. Rising temperatures force mountain plants to move upwards until they reach the highest elevations and become locally extinct (i.e., the 'summit trap phenomenon'; e.g., [11]).

The current extinction rates of plant species are between 100 and 1000 times greater when compared to natural extinction rates and every 2 years our planet is losing at least one potential major medicinal plant [12]. This rapid rate of extinction and the resulting decline in biodiversity is caused by a combined impact of factors such as urbanization, the overexploitation of natural resources and the pollution of soil, water, and air [13]. Therefore, many international agreements explicitly stress the urgency to document and preserve the floristic and cultural diversity before it is lost (e.g., $[14,15])$.

As in other mountain regions in so-called developed countries, changes in the culture and socio-economy of the European Alps in the twentieth century have led to the deterioration of much of the region's traditional ecological knowledge (see, e.g., [16]) and biodiversity [17, 18]. Despite this process of erosion however, public interest in folk medicine has steadily increased in recent years, highlighting the importance of traditional ecological knowledge for promoting sustainable land management including organic farming, eco-tourism, and eco-gastronomy [19-21]. This can revitalize the relationship between man and nature and help preserving biodiversity and the local cultural heritage in the Alps.

Among the regions of the European Alps, South Tyrol (Southern Alps, Northern Italy) is one of the most interesting from an ethnobotanical standpoint. The interaction of a great floristic richness and a long-lasting cultural history has resulted in a unique ethnopharmacological knowledge within the local population, which can be traced back to prehistoric times [22, 23]. Local literature documents the richness of medicinal plants and related traditional medicinal practices. To our knowledge, no scientific study has jointly addressed both, the ethnobotanical and ecological aspects of medicinal plants, from an interdisciplinary perspective.

Therefore, our study aims to close this gap by (1) compiling and analyzing existing ethnobotanical knowledge on traditional medicinal plants in South Tyrol, (2) assessing the current state of the local diversity of medicinal plants and associated cultural heritage, and (3) highlighting local plant resources of particular interest for regional conservation and/or sustainable agriculture and eco-tourism activities.

\section{Methods}

\section{Study area}

The study area, the Autonomous Province of South Tyrol, is the most northern province of Italy and is situated in the Central Alps, south of the Alps' main ridge (Fig. 1). The typical mountainous landscape of the region is highly heterogeneous [26] and covers around $7400 \mathrm{~km}^{2}$. About $40 \%$ of the land is above $2000 \mathrm{~m}$ above sea level. Altitudes range from $194 \mathrm{~m}$ to a maximum of $3893 \mathrm{~m}$ with the Ortler being the highest peak of South Tyrol.

The climate of South Tyrol is intermediate between mountain and Mediterranean climate, with a high relative sunshine duration and a low precipitation compared to the neighboring regions [27]. Over half of the area is forested, predominantly by spruce (Picea abies) and pine (Pinus sylvestris, P. cembra), accompanied by mixed forest with beech (Fagus sylvatica) and fir (Abies alba). One-third of the region is covered by agricultural land and $14 \%$ by alpine grassland, glaciers, and rocky areas. Only 3\% of the area is classified as settlement area [25]. Typically, the higher altitudes are sparsely populated, while the valleys are characterized by orchards (i.e., apple and grapes) and dense urban areas.

The South Tyrolean Alps harbor 2169 native vascular plant species including many rare and endemic species of which about $25 \%$ are endangered and appear in the Red List $[28,29]$. Those plant species used for medicinal purposes are very popular in local narratives of the three different linguistic groups that coexist in the South Tyrol; Germans (69\%), Italians (26\%), and Ladine (5\%; see Fig. 1; $[25,30])$. Prior to the twentieth century, South Tyrol was characterized by secluded mountain farms and the local population was highly dependent on natural resources for their livelihoods. Native plants were the most important and often the only accessible form of medicine. Thus, over the centuries, unique medical traditions and a variety of vernacular names for medicinal plants developed [31].

In the twentieth century, however, the social, political, and economic structure changed fundamentally and this led to significant ecological degradation and cultural erosion. In the first half of the century, the annexation of the region by Italy and related impacts left deep distortions in the cultural identity of the people [32]. In the 1970s, a rapid economic upswing led to drastic transformations of the social and economic systems in the region that were related to South Tyrol's political claim of autonomy from Italy. Changes in land use, both the 


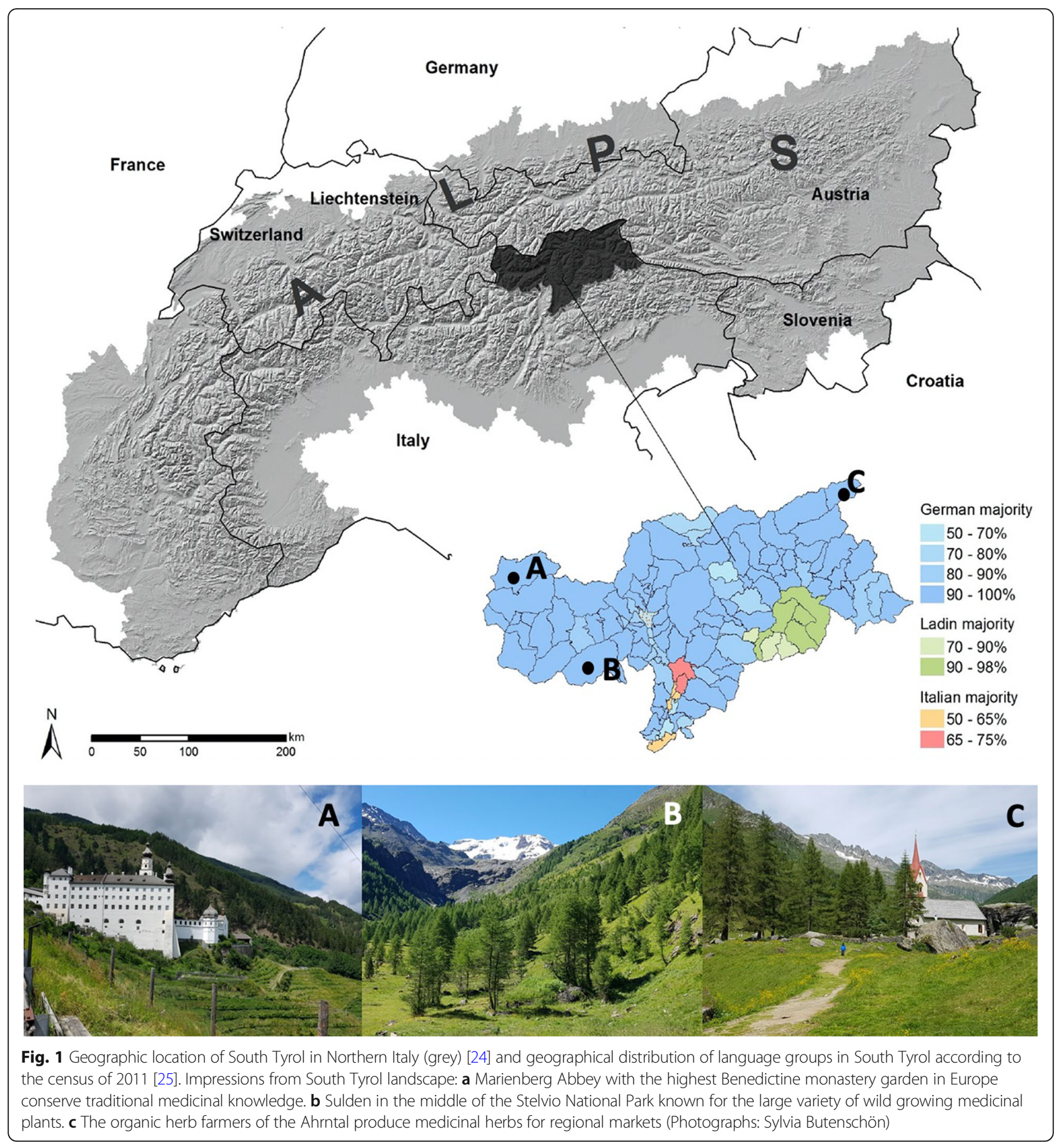

abandonment of mountain pastures and the intensification in the valleys, combined with socioeconomic and environmental processes (tourism, urbanization, pollution, etc.), have dramatically deteriorated the culture and natural environment [22, 32, 33].

\section{Data collection}

Following the PRISMA guidelines [34], we conducted a qualitative review of all publications written in English on alpine medicinal species in the Web of Science by using keywords that cover the medicinal and alpine species (see Appendix A for details). The advanced keyword search (last update March 2020) in the Web of Science revealed 149 references related to medicinal alpine species in the "topic" or "title" fields, more than the 80\% (125) have been published since 2008. Numerous papers focus on geographical regions that were not relevant to our study (e.g., India, Nepal, China, USA, Pakistan, Denmark); thus, we 
filtered the results and kept 31 articles from Alpine European countries such as Italy, Switzerland, Austria, France, Germany, and neighboring alpine regions. In a first step, we screened the titles and abstracts of the remaining articles and eliminated articles that are not related to our topic (10; e.g., genetic surveys or physiological studies of one species). We retained two ethnoveterinarian studies $[35,36]$ for the next step of the review process. Second, we eliminated any articles that lacked access to a full text version and sent requests to the authors of the most relevant ones. Third, we conducted a full text review of the remaining 21 articles in order to gather relevant information. The whole process was conducted independently by two reviewers who jointly reported a synthesis in Appendix A. Data on medicinal plants of the Alps are mainly based on interviews of local (mostly elderly) people (Appendix A, [22, 23, 26]).

As scientific literature in Web of Science mostly did not cover our study region, we reviewed other published and unpublished material through local library research and through recommendations from local medicinal herb experts. In so doing, we documented traditionally used medicinal plants of South Tyrol in order to capture the total diversity of plants and usages in our study area. Almost all literature was published between 1988 and 2018, including books for the non-expert public and other documents that focused exclusively on the medical usage of plants of local relevance. Thus, the literature covers the period of the upcoming herbal medicine trend in the 1990s and is based mainly on reviving knowledge from old folk medicinal practices (Appendix A). The widespread use of popular books that sometimes lack a certain scientific rigor, however, but reflects the knowledge base of local communities that in other studies was addressed by semi-structured interviews (Appen$\operatorname{dix} \mathrm{A} ;[31])$. This knowledge was passed on from parents to children, often from mothers to daughters. The current increasing interest in medicinal species today, however, cannot rely on the exchange between the generations and often relies on popular science books and websites about medicinal herbs and medicinal plants. Physicians and pharmacists who are interested in herbal remedies often use recognized textbooks as important sources of information about herbs [37]. Altogether, 17 sources were used, including 16 books and one unpublished work (see Appendix A). The 17 sources were comprised of three types: (1) cultural literature $(n=7)$, (2) prescription books $(n=9)$, and (3) scientific manuscripts $(n=2$; [31], Appendix A, 42). Furthermore, the level of originality of literature was classified into three categories: (1) original information based on interviews or authors' expert knowledge $(n=7)$, (2) secondary literature that compiled information from the local literature $(n=8)$, and (3) a mix of both $(n=3$; see details in
Appendix A). Only references on South Tyrol were included in further analysis (Appendix C).

Plant species given in the references and their nomenclature where vetted through the online platform "Flora Fauna Südtirol" [38] for vascular plants, the "Information System on Italian Lichens" [39], and the Italian Mycological Association [40]. Finally, the nomenclature was standardized according to "The Plant List" [41]. Data acquired for each plant species included vernacular names, plant parts used, use categories, medicinal use, temporal changes in use, the pharmacological or phytochemical evidence on medicinal use, cultivation, natural habitat, as well as endangerment and protection status. Vernacular names are important in the ethnobotanical cosmos as medicinal plants are known, collected and traded as products with local names in folk taxonomies (e.g., $[42,43])$.

\section{Data analysis}

We assessed the total diversity and various uses of medicinal plants by reviewing their general usage and the procurement of species, medicinal use of species, as well as pharmacological or phytochemical evidence for the medicinal healing effect of species. We recorded a number of citations per species (Fig. 3). These parameters were highlighted from both the ecological and cultural perspective. Species diversity comprises the number of

Table 1 Use versatility of traditional medicinal plants of South Tyrol

\begin{tabular}{|c|c|c|c|}
\hline Use type & Count & $\begin{array}{l}\text { Most frequent } \\
\text { plant families }\end{array}$ & Examples of plant species \\
\hline Medicine & 276 & $\begin{array}{l}\text { Asteraceae, } \\
\text { Rosaceae }\end{array}$ & $\begin{array}{l}\text { Arnica montana, Hypericum } \\
\text { perforatum, Equisetum arvense, } \\
\text { Peucedanum ostruthium, Plantago } \\
\text { lanceolata, Sambucus nigra }\end{array}$ \\
\hline Alimentary & 128 & Rosaceae & $\begin{array}{l}\text { Gentiana lutea, Juniperus } \\
\text { communis, Pinus cembra, Rosa } \\
\text { canina, Sambucus nigra, Thymus } \\
\text { pulegioides }\end{array}$ \\
\hline Veterinary & 70 & Asteraceae & $\begin{array}{l}\text { Cetraria islandica, Dryopteris filix- } \\
\text { mas, Geranium robertianum, Larix } \\
\text { decidua, Leontopodium nivale, } \\
\text { Peucedanum ostruthium }\end{array}$ \\
\hline Spiritual & 55 & Asteraceae & $\begin{array}{l}\text { Arnica montana, Crataegus } \\
\text { monogyna, Peucedanum } \\
\text { ostruthium, Hypericum perforatum, } \\
\text { Juniperus communis, Salix alba, } \\
\text { Sambucus nigra }\end{array}$ \\
\hline Cosmetics & 44 & Asteraceae & $\begin{array}{l}\text { Betula pendula, Leontopodium } \\
\text { nivale, Matricaria chamomilla, } \\
\text { Pinus mugo, Urtica dioica, } \\
\text { Trifolium repens }\end{array}$ \\
\hline Domestic & 43 & $\begin{array}{l}\text { Fagaceae, } \\
\text { Pinaceae and } \\
\text { Rubiaceae }\end{array}$ & $\begin{array}{l}\text { Betula pendula, Equisetum arvense, } \\
\text { Fraxinus excelsior, Galium aparine, } \\
\text { Larix decidua, Malva sylvestris, } \\
\text { Pinguicula alpina }\end{array}$ \\
\hline
\end{tabular}


Table 2 Endangered and protected medicinal plants species used in traditional folk medicine in the region of South Tyrol according to [29]

\begin{tabular}{|c|c|c|}
\hline $\begin{array}{l}\text { Red-list } \\
\text { status }\end{array}$ & Count & Species \\
\hline Extinct & 2 & Eryngium amethystinum, Eryngium campestre \\
\hline $\begin{array}{l}\text { Critically } \\
\text { endangered }\end{array}$ & 1 & $\begin{array}{l}\text { Cetraria islandica, Mentha pulegium, Usnea } \\
\text { barbata }\end{array}$ \\
\hline Endangered & 4 & $\begin{array}{l}\text { Cyanus segetum, Dipsacus fullonum, Marrubium } \\
\text { vulgare, Rosa montana, Usnea dasypoga }\end{array}$ \\
\hline Vulnerable & 8 & $\begin{array}{l}\text { Adiantum capillus-veneris }{ }^{\mathrm{a}} \text {, Allium ursinum, } \\
\text { Gentiana lutea }^{\mathrm{b}} \text {, Hyoscyamus niger, llex } \\
\text { aquifolium }^{\mathrm{a}} \text {, Anacamptis morio }{ }^{\mathrm{a}} \text {, Primula } \\
\text { matthioli }{ }^{\mathrm{a}} \text {, Quercus robur }\end{array}$ \\
\hline $\begin{array}{l}\text { Near } \\
\text { threatened }\end{array}$ & 11 & $\begin{array}{l}\text { Althaea officinalis, Centaurium erythraea }{ }^{a}, \text { Drosera } \\
\text { rotundifolia }{ }^{a} \text {, Galega officinalis, Leonurus } \\
\text { cardiaca, Lilium bulbiferum }{ }^{a} \text {, Malva alcea, } \\
\text { Menyanthes trifoliata, Nasturtium officinale, } \\
\text { Nepeta cataria, Salix pentandra }\end{array}$ \\
\hline Least concern & 238 & 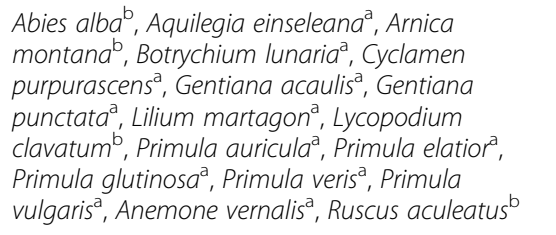 \\
\hline Data deficient & 2 & Alchemilla alpina, Alchemilla xanthochlora \\
\hline Not evaluated & 11 & $\begin{array}{l}\text { Aesculus hippocastanum, Fomitopsis officinalis, } \\
\text { Lamium galeobdolon, Heracleum sphondylium, } \\
\text { Lepidium sativum, Fomitopsis betulina, Ribes } \\
\text { petraeum }\end{array}$ \\
\hline
\end{tabular}

used species, botanical and fungal families, growth forms, and altitudinal habitat range. We recorded usage and procurement of species, the (plant) parts most frequently used, whether the plant is collected in the wild or cultivated, as well as whether the plant is used often or has been abandoned. The general use possibilities were grouped into (1) medicinal use, (2) alimentary, (3) veterinary, (4) spiritual, (5) cosmetic, and (6) domestic (Table 1).

We compared the variation of the number of citations, vernacular names, use versatility, and number of medicinal uses between wild and cultivated species; between species with different protection status (i.e., non, partially protected and protected); between species of different Red List categories (e.g., extinct, extinct in the wild, critically endangered, endangered, vulnerable, nearly threatened, least concern); and between different growth forms (i.e., herbs or woody species) and pharmacological or phytochemical evidence of medicinal effects (i.e., positive or negative effect and not investigated). We used the Kruskal-Wallis $H$ test followed by the Dunn post-hoc test. We also conducted statistical analyses with the open-source software package R, version 3.3.2 (R Foundation for Statistical Computing, Vienna, Austria).
We sorted and categorized medicinal plant use and ailments treated according to the International Classification of Primary Care (ICPC-2) [44]. By doing so, we differentiated between 12 disease categories (Table 3). Based on [45], the ICPC categories are more suitable for ethnopharmacological studies than other classifications. Pharmacological or phytochemical evidence of the medicinal healing effect of plant substances and medicinal products was determined by monographs from the German Commission E [46] and of the European Medicines Agency (EMA; [47]). These categories are also in line with many ethnobotanical studies, as previously reported by [48].

For our quantitative analysis, we calculated the ethnobotanicity index (EI: percentage of useful plants from the total flora of the region; see [49] and the ethnophytonomic index (EPI: ratio between reported plants with vernacular names and the total flora of the studied region; see [50]). The latter indicates the richness of people's knowledge of local plants.

\section{Results \\ Qualitative and quantitative characterization of medicinal species}

We named a maximum of 155 , a minimum of 18 , and an average of 72 plant species per source. On average, the prescription books (mean 72) mentioned more plant species than the books on regional history (mean 60). Four of the 17 references are dated to before 2000, while 13 were published after 2000. Thus, the number of books on the topic after 2000 has tripled. This increase reflects the new social trend of herbal remedy use [51].

We identified a total of 275 native medicinal species that are used (Appendix C), including 204 herbs, 28 trees, 28 shrubs, 9 ferns, 3 mushrooms, and 3 lichens. The species belonged to 72 families, of which Asteraceae, with 32 species, was most frequent, followed by Rosaceae (25), Lamiaceae (18), Apiaceae (15), and Brassicaceae (10). For mushrooms, it was Fomitopsidaceae and for lichens Parmeliaceae. About 21\% (59 species) of all species are classified as biogeographically Alpine while the remaining species have a cosmopolitan character. The species most frequently cited in our literature sources were Hypericum perforatum and Urtica dioica (cited in more than 90\% of used sources) followed by Plantago lanceolata (cited in more than $85 \%$ of used sources; Fig. 3). Furter, 211 plants were collected in the wild, while 64 plants were cultivated in traditional home gardens or on agricultural land. The plant parts most frequently mentioned in literature for their potential use were leaves (41\%), flowers, and buds (28\%) as well as bulbs and roots (17\%). Less commonly used were fruits (7\%), bark and resin (5\%), and seeds (2\%).

At least 17 plant species were reported to be no longer used in South Tyrol (i.e., Artemisia vulgaris, Euphrasia 
officinalis, Galium verum, Pimpinella saxifraga, Adiantum capillus-veneris, Botrychium lunaria, Sedum roseum, Fomitopsis betulina, Polygala chamaebuxus, Viola biflora, Mutellina adonidifolia, Primula matthioli, Primula auricula, Antennaria dioica, Biscutella laevigata, Beckwithia glacialis, Silene vulgaris). In terms of health benefits, among these species, there are only two species (Antennaria dioica, Euphrasia officinalis) with negative effects and one species (Mutellina adonidifolia) with a positive effect that has been proven by pharmacological or phytochemical evidence. There are no studies available for $80 \%$ of the species that are no longer used. All of the species are wild and $76 \%$ are herbs. Four species (Adiantum capillus-veneris, Botrychium lunaria, Primula auricula, and Primula matthioli) are protected species; Adiantum capillus-veneris, Primula matthioli, and the mushroom Fomitopsis betulina are classified as vulnerable or nearly threatened species at the Red List (Table 2).

We found that use versatility was high among the recorded species (see Appendix C). In addition to medicinal applications, $46 \%$ of the species were also used in alimentary settings, $25 \%$ for veterinary purposes, $20 \%$ for spirituality and cults, $16 \%$ as cosmetics, and $16 \%$ for domestic purposes (Table 1). The species with the highest versatility (i.e., 5 out of the 6 above-mentioned purposes) were the perennial herbs Alchemilla xanthochlora,
Artemisia absinthium, Equisetum arvense, Hypericum perforatum, Lilium bulbiferum, Urtica dioica, and Valeriana officinalis; the dwarf shrub Thymus pulegioides; and the woody species Betula pendula, Corylus avellana, Quercus petraea, Q. pubescens, Q. robur, and Sambucus nigra (Fig. 3). About one-third of the species (34\%) were reported for their exclusive use in only one of the categories while another third (31\%) were used for two purposes, $19 \%$ for three, and $10 \%$ for four different purposes. The so-called Heublumen ("hay flowers") mix is a blend of flowers, seeds, smaller leaves, and stem pieces of various mowed grassland plants.

Plants were most frequent used for the digestive system, skin, and for the respiratory system. These medicinal applications also included the highest number of useful plants (Table 3). Other relevant remedies included general and non-specific disorders (11\%), the musculoskeletal system $(10 \%)$, the urinary tract $(8 \%)$, as well as the neurological and circulatory system (both $8 \%$ ). Fewer plant species were used to treat disorders of pregnancy and childbirth, or for family planning (5\%). Even fewer were used to treat disorders of the eye (3\%), the endocrine system, the nutritional system and metabolism (3\%), or for psychological issues (2\%). A very high percentage of plants $(70 \%)$ were used as multi-contextual remedies for several disorders ( $2-5$ categories). The remaining species (14\%) were useful in more than five

Table 3 Medicinal use spectrum of traditional medicinal plants in South Tyrol, classified into 12 human disorder categories based on the International Classification of Primary Care (ICPC-2) [44]. The category nutraceuticals is based on plants that have been reported as either being eaten or consumed as a beverage for their medicinal use

\begin{tabular}{|c|c|c|c|c|}
\hline Disorders & Plants & $\begin{array}{l}\text { Most frequent plant } \\
\text { families }\end{array}$ & Examples of plant species & $\begin{array}{l}\text { Nutraceutical food } \\
\text { plants }\end{array}$ \\
\hline Digestive & 152 & Asteraceae & $\begin{array}{l}\text { Achillea millefolium, Centaurium erythraea, Gentiana lutea, } \\
\text { Peucedanum ostruthium }\end{array}$ & 91 \\
\hline Skin & 133 & Asteraceae & $\begin{array}{l}\text { Chelidonium majus, Equisetum arvense, Hypericum perforatum, } \\
\text { Plantago spp. }\end{array}$ & 65 \\
\hline Respiratory & 128 & Asteraceae & $\begin{array}{l}\text { Cetraria islandica, Primula glutinosa, Pimpinella saxifraga, Pinus } \\
\text { mugo }\end{array}$ & 73 \\
\hline General and unspecified & 102 & Asteraceae & $\begin{array}{l}\text { Arnica montana, Pinus cembra, Pimpinella major, Thymus } \\
\text { pulegioides }\end{array}$ & 63 \\
\hline Musculoskeletal & 93 & Asteraceae & $\begin{array}{l}\text { Arnica montana, Larix decidua, Potentilla anserina, Stachys } \\
\text { sylvatica, Symphytum officinale }\end{array}$ & 43 \\
\hline Urology & 80 & Asteraceae & Achillea moschata, Alchemilla alpina, Juniperus communis & 45 \\
\hline Neurological & 76 & Asteraceae & Crataegus monogyna, Humulus lupulus, Hypericum perforatum & 34 \\
\hline Cardiovascular & 74 & Rosaceae & $\begin{array}{l}\text { Achillea millefolium, Allium spp., Crataegus monogyna, Leonurus } \\
\text { cardiaca, Viscum album }\end{array}$ & 51 \\
\hline $\begin{array}{l}\text { Pregnancy, Childbirth, } \\
\text { Family Planning }\end{array}$ & 49 & Asteraceae & $\begin{array}{l}\text { Adiantum capillus-veneris, Artemisia vulgaris, Geranium } \\
\text { robertianum }\end{array}$ & 33 \\
\hline Eye & 29 & Orobanchaceae & Daucus carota, Euphrasia spp., Pimpinella saxifraga, & 14 \\
\hline $\begin{array}{l}\text { Endocrine/Metabolic and } \\
\text { Nutritional }\end{array}$ & 26 & Rosaceae & Cichorium intybus, Taraxacum campylodes & 19 \\
\hline Psychological & 19 & $\begin{array}{l}\text { Equisetaceae and } \\
\text { Rosaceae }\end{array}$ & $\begin{array}{l}\text { Melissa officinalis, Pinus cembra, Valeriana officinalis, Sedum } \\
\text { roseum }\end{array}$ & 17 \\
\hline
\end{tabular}




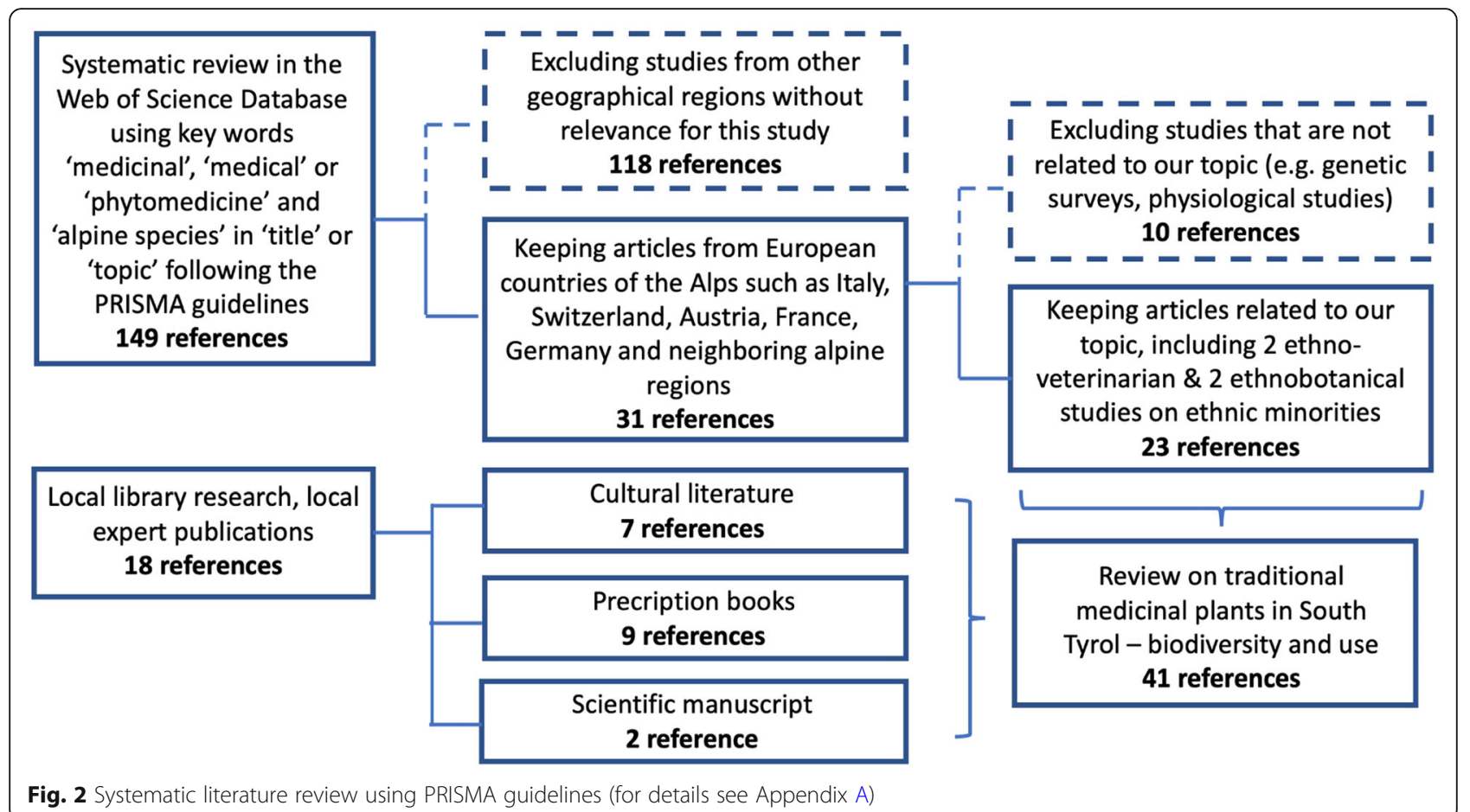

categories and thus were often referred to as universal remedies (in German: "Allheilmittel" or "Heil aller Schäden"). Among these, we found Equisetum arvense, Juniperus communis, and Peucedanum ostruthium (Fig. 3).

For $42 \%$ of the recorded species $(N=111)$, we found evidence of their medicinal significance in the German database [46]. For 79 of these species, the medicinal purpose has been validated, while for 33 it was rejected. This means that these 33 species are not curative or have severe and even toxic side effects when used. In the European database [47], the medicinal significance of 57 species (21\%) were assessed, 215 (78\%) were not listed, and 3 species (1\%) were registered that their medicinal significance was under discussion.

Species with a higher number of citations (cf) and vernacular names (vn) in folk medicinal literature, as well as more use versatility (uv), or a greater number of medicinal uses $(\mathrm{mu})$ have been subjected to scientific studies that have proven positive effects more often (Kruskal-Wallis $\mathrm{Chi}^{2}{ }_{\mathrm{cf}}=63.5, p_{\mathrm{cf}}<0.0001 ; \mathrm{Chi}^{2}{ }_{\mathrm{vn}}=25.1$, $p_{\mathrm{vn}} \leq 20090.0001 ; \mathrm{Chi}^{2}{ }_{\mathrm{uv}}=22.9, p_{\mathrm{uv}}<0.0001 ; \mathrm{Chi}^{2}{ }_{\mathrm{mu}}=$ $33.2, p_{\mathrm{mu}}<0.0001$; see Fig. 4). However, the majority (59\%) of native South Tyrolean medicinal species remains understudied.

We found a total of 714 vernacular names used in traditional South Tyrolean folk medicine that referred to 276 actual species (Appendix B). Thirty-seven of them were quoted with one vernacular name and a few species even had more than 10 names-for example, 17 names for Achillea millefolium, Hypericum perforatum, and Juniperus communis and 18 names were found for $\mathrm{Al}$ chemilla xanthochlora (e.g., "Frauenhilf," women's help, herb to treat gynecological disorders) and Arnica montana (e.g. "Donnerblüml," thunder flower, protection from thunderstorms or "Wundkräutl," wound herb, herb for wound treatment) (Fig. 3 and Appendix B, C). For 66 species, no local names were indicated.

Frequency of citation in folk medicinal literature (cf), number of vernacular names (vn), or number of medicinal uses $(\mathrm{mu})$ are not related to the growth form of the species (Kruskal-Wallis $\mathrm{Chi}^{2}{ }_{\mathrm{cf}}=7.6, p_{\mathrm{cf}}=0.270 ; \mathrm{Chi}^{2}{ }_{\mathrm{vn}}=$ $\left.4.4, p_{\mathrm{vn}}=0.622 ; \mathrm{Chi}^{2}{ }_{\mathrm{mu}}=9.5, p_{\mathrm{mu}}=0.149\right)$. Woody species have a significant higher number of use versatility (uv; $\mathrm{Chi}^{2}{ }_{\mathrm{uv}}=29.1, p_{\mathrm{uv}}<0.001^{* * * *}$; see Fig. 5).

\section{Ethnobotanicity and ethnophytonomic index}

Two thousand one hundred sixty-nine vascular species are native to South Tyrol [28]. Considering the large number of vernacular names for the medicinal plants in the local flora, the calculated ethnophytonomic index (EPI) (0.102) indicates that popular knowledge about native plants was very rich. The ethnobotanicity index (EI) for medicinal plants was $12 \%$, thus about every eighth plant of the local flora is used in folk medicine.

\section{Assessment of vulnerability}

According to the regional Red List [29], a total of 24 species are listed as endangered, including one that is 


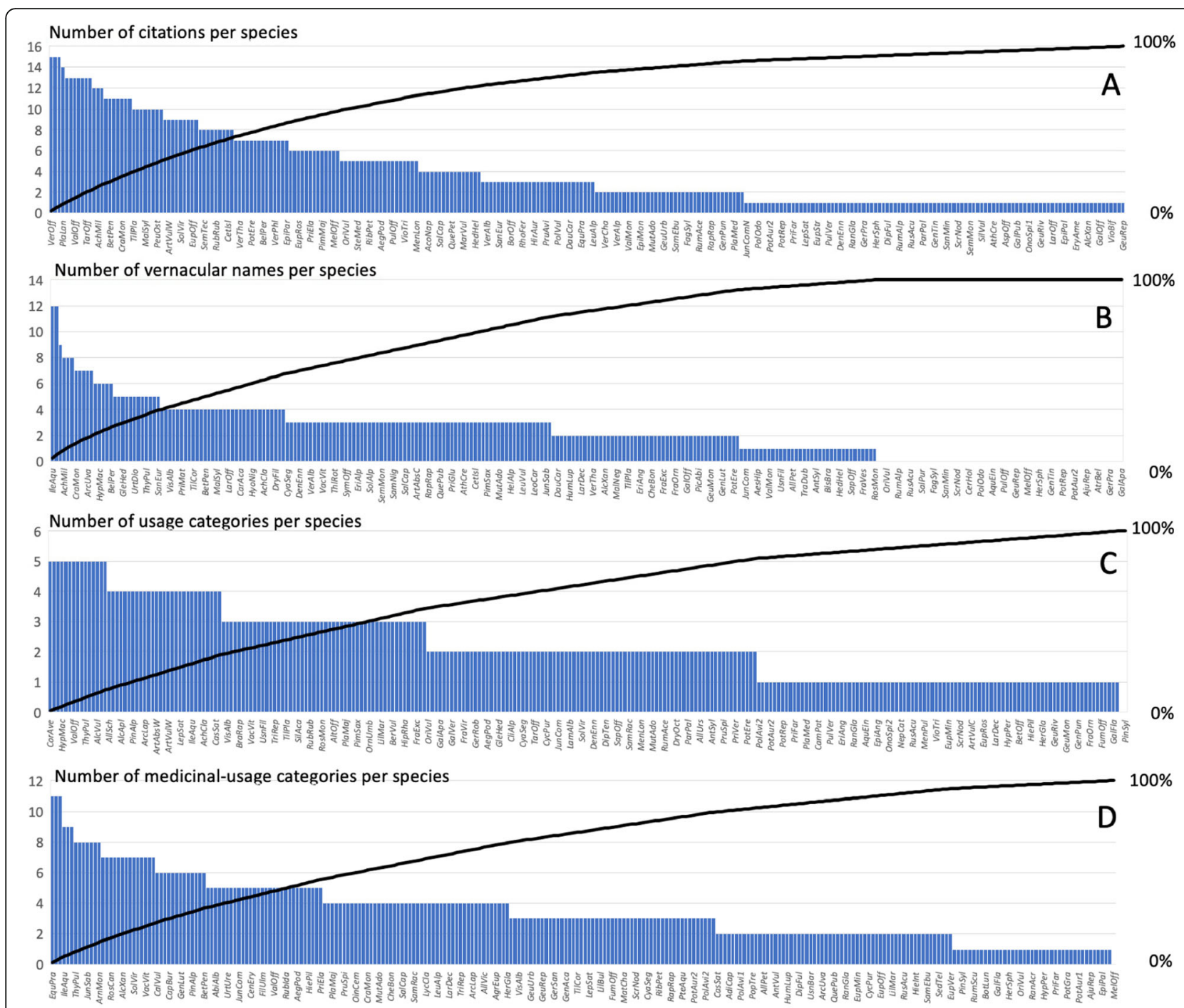

Fig. 3 The most frequent cited traditional medicinal plant species in South Tyrol. The number of citations per species (a), vernacular names (b), usage categories (c), and medicinal-usage categories (d) are given. The abbreviation of species names consists of the first three letters of the genus name and the first three letters of the specific name (e.g., HypPer = Hypericum perforatum; AlcVul = Alchemilla vulgaris). The Pareto line is also given. Full list is provided in Appendix C

critically endangered (Mentha pulegium), four endangered (Cyanus segetum, Dipsacus fullonum, Marrubium vulgare, and Rosa montana), 9 vulnerable, and 11 nearly threatened species (Table 2). Two species (Eryngium amethystinum and Eryngium campestre) were listed as extinct. With regard to the protection status, we found that about 95 of the medicinal species (35\%) were under the protection status of the regional legislation (Table 2). Of those, 19 species (7\%) were strictly protected, while five (Abies alba, Arnica montana, Gentiana lutea, Lycopodium clavatum, and Ruscus aculeatus) were under partial protection, meaning that permission for extraction from nature or use can be granted through exceptions issued by the regional authority.
Frequency of citation in folk medicinal literature (cf), use versatility (uv), or number of medicinal uses (mu) are not related to the protection status of the species (Kruskal-Wallis $\mathrm{Chi}^{2}{ }_{\mathrm{cf}}=2.8, p_{\mathrm{cf}}=0.224 ; \mathrm{Chi}^{2}{ }_{\mathrm{vn}}=2.2$, $\left.p_{\mathrm{vn}}=0.331 ; \mathrm{Chi}^{2}{ }_{\mathrm{mu}}=3.7, p_{\mathrm{mu}}=0.158\right)$. Non-protected species have significantly more vernacular names (vn; $\mathrm{Chi}^{2}{ }_{\text {uv }}=7.4, p_{\text {uv }}=0.024^{*}$; see Fig. 5e). Frequency of citation in folk medicinal literature (cf), number of vernacular names (vn), use versatility (uv), or number of medicinal uses $(\mathrm{mu})$ are not related to the status of the species on the local Red List (Kruskal-Wallis $\mathrm{Chi}^{2}{ }_{\mathrm{cf}}=$ 6.6, $p_{\mathrm{cf}}=0.471 ; \mathrm{Chi}^{2}{ }_{\mathrm{vn}}=8.9, p_{\mathrm{vn}}=0.263 ; \mathrm{Chi}^{2}{ }_{\mathrm{uv}}=8.2$, $\left.p_{\mathrm{uv}}=0.316 ; \mathrm{Chi}^{2}{ }_{\mathrm{mu}}=13.2, p_{\mathrm{mu}}=0.067\right)$.

Out of the 276 medicinal plants, about 59 species (21\% of all native medicinal species) can be 
Table 4 Medicinal species in South Tyrol that are predominately alpine according to [52] and with the altitudinal range alp = alpine, sniv = sub-nival, suba = sub-alpine, mont = montane, and coll = colline; in bold = predominantly alpine occurrence (according to [22])

\begin{tabular}{|c|c|c|}
\hline $\begin{array}{l}\text { Altitudinal } \\
\text { range }\end{array}$ & Count & Plant species \\
\hline alp-sniv & 5 & Achillea atrata, Achillea moschata, Geum reptans, Beckwithia glacialis, Veronica alpina \\
\hline Alp & 2 & Dryas octopetala, Silene acaulis \\
\hline suba-sniv & 3 & Leucanthemopsis alpina, Hieracium intybaceum, Salix serpyllifolia \\
\hline suba-alp & 14 & $\begin{array}{l}\text { Aconitum napellus, Alchemilla alpina, Allium victorialis, Artemisia mutellina, Cetraria islandica, Erigeron alpinus, Geum } \\
\text { montanum, Juniperus communis var. saxatilis, Mutellina adonidifolia, Primula glutinosa, Anemone vernalis, Rhododendron } \\
\text { ferrugineum, Sempervivum montana, Thlaspi rotundifolium }\end{array}$ \\
\hline mont-alp & 20 & $\begin{array}{l}\text { Achillea clavennae, Arctostaphylos uva-ursi, Arnica montana, Clinopodium alpinum, Gentiana acaulis, Gentiana lutea, } \\
\text { Gentiana punctata, Leontopodium nivale, Peucedanum ostruthium, Pinus cembra Potentilla aurea, Primula auricula, Rumex } \\
\text { alpinus, Sedum atratum, Sempervivum tectorum, Soldanella alpina, Vaccinum myrtillus, Vaccinium vitis-idaea, Viola biflora }\end{array}$ \\
\hline mont-suba & 6 & Botrychium lunaria, Chenopodium bonus-henricus, Erica carnea, Pinus mugo, Rosa pendulina, Veratrum album \\
\hline coll-alp & 5 & Antennaria dioica, Biscutella laevigata, Globularia cordifolia, Parnassia palustris, Primula farinosa \\
\hline coll-suba & 4 & Calluna vulgaris, Carlina acualis, Polygala chamaebuxus, Thymus pulegioides \\
\hline
\end{tabular}

phytogeographically considered to be alpine (Table 4). However, some of those (e.g., Arnica montana and Vaccinium vitis-idaea) can also be found at lower elevations. In our study, we identified at least ten medicinal species that are restricted to the upper alpine zone (> $2600 \mathrm{~m}$ a.s.l.) which are the perennial herbs Achillea atrata, Achillea moschata, Dryas octopetala, Geum reptans, Hieracium intybaceum, Leucanthemopsis alpina, Beckwithia glacialis, Silene acaulis, and Veronica alpina and the woody species Salix serpyllifolia.
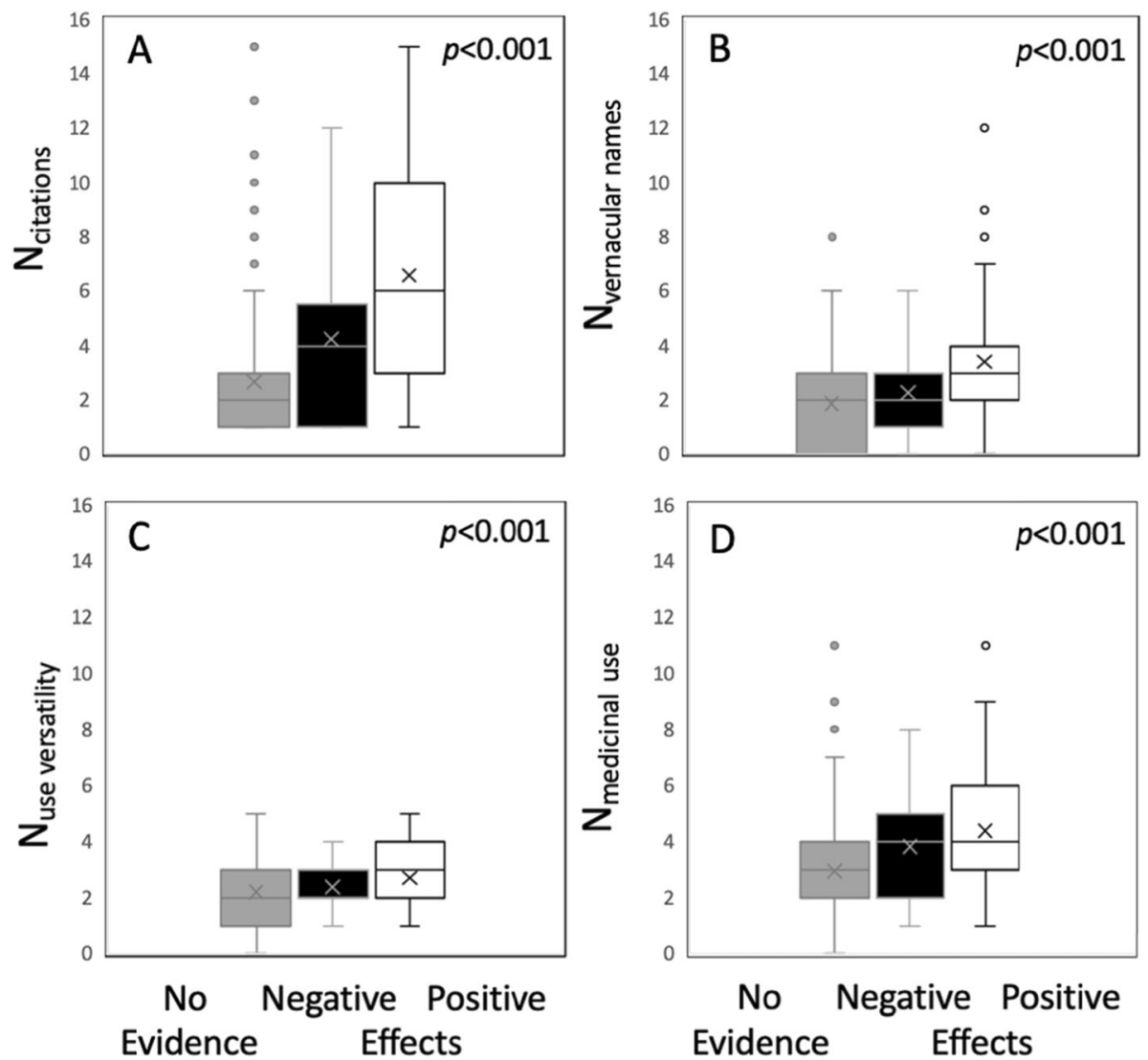

Fig. 4 Comparison of species without pharmacological or phytochemical evidence, with evidence of negative and of positive effects regarding number of citations in folk medicinal literature (a), number of vernacular names (b), overall use versatility (c), and medicinal use versatility (d) in South Tyrol. For results of the Kruskal-Wallis rank sum test, see text 


\section{Discussion}

South Tyrol as a hotspot of traditional medicinal plants Our study explores the local pharmacopoeia of South Tyrol, a region which has thus far been poorly investigated in ethnopharmacological studies when compared to neighboring regions [53-55].

Herbs dominate South Tyrolian medicinal species, followed by woody species. Ferns, mushrooms, and lichens are less frequently used (Appendix C). Woody species have a higher overall use versatility when compared to herbs (Fig. 5f) which is related to the variety of plant parts used such as leaves, bark, roots, or flowers.

Similar to other studies on traditional medicinal plant use (e.g., Appendix A [22, 23]), the South Tyrolian species are predominately cosmopolitan, only $20 \%$ are alpine (Table 4). Biogeographically, 16 of the 20 most cited plants are also found in other parts of Europe, while four grew only in alpine areas. Thirty-five percent of the medicinal species are classified as threatened or protected species (Table 2). In general, non-protected species are of higher importance for medicinal or veterinarian use than protected species (Fig. 5e). Cultivated medicinal species are dominant and thus, in contrast to other more pristine mountain regions (e.g., [56] in Himalaya or [57] in Ethiopian Highlands), overexploitation is not a current issue in South Tyrol. This has also been reported for other regions with long phytomedicinal traditions (e.g., [58] from Central China or [59] from the Balkan Mountains). However, extinction processes due to overharvesting may already have run their course in the Alps. Medicinal species that are currently in use mainly grow in the bottom of valleys rather than at high alpine zones [22].

Twelve percent of all South Tyrolean species are used in traditional folk medicine. This proportion ranks among the highest in the European alpine regions and is similar to the Basque country and the neighboring Swiss region of Prättigau. The proportion is twice as high as in the Albanian Alps (Table 5). The ethnobotanicy index for South Tyrol is higher than in other mountain regions of Italy and demonstrates a broad local knowledge of medicinal species. Thus, despite land use changes and industrialization processes, local ethnopharmacological heritage is still being preserved among elders and inhabitants of rural areas (e.g., [31]) and in popular science books (Appendix A). South Tyrol's EI is similar to the global average value for medicinal plants (12\%), see [64].

A high number of vernacular names for medicinal species underlines that popular knowledge of medicinal plants in South Tyrol is still well consolidated (Fig. 3; Appendix B). However, the generally lower IE values in some regions (Table 5) may indicate a more rapid process of cultural erosion and a loss of ethnopharmacological knowledge [60, 65]. Ethnobotanical studies on wild and cultivated plants used as food and medicine by the other ethnic minority in the Alps reported that traditional knowledge on plant names and uses was limited to the older generations (Appendix, [22, 23]).

When estimated by the rarely used ethnophytonomic index (EPI 0.10), popular knowledge of wild species is widespread, exceeds the previously reported value for Sondrio (0.06; [3]), and is comparable to the Central Alps (0.10; [54]).

By comparing the 20 most cited plants with those that had the most vernacular names, we can observe two general trends. Firstly, 10 of the most cited plants were not among the top 20 plants with the most vernacular names but they have become popular nowadays, e.g., Matricaria chamomilla, Plantago lanceolata, Rosa canina, and Urtica dioica. The high popularity of these species in the region may be attributed to the fact that they appear in most phytotherapy books. Secondly, the 20 plants with the most vernacular names include a higher number of alpine plants (7), which is typical for the alpine environment of the study area, e.g., Carlina acaulis, Leontopodium nivale, and Peucedanum ostruthium. The count of local names is more likely to reflect the original medicinal plants, whereas the most

Table 5 Overview of various ethnobotanical studies of mountain regions in Europe

\begin{tabular}{|c|c|c|c|c|c|c|}
\hline \multirow[t]{2}{*}{ Reference } & \multirow[t]{2}{*}{ Country/Region } & \multirow{2}{*}{$\begin{array}{l}\text { Study } \\
\text { area }\end{array}$} & \multicolumn{2}{|c|}{ Number of species } & \multirow[t]{2}{*}{ El } & \multirow[t]{2}{*}{ Source } \\
\hline & & & Total flora & MP & & \\
\hline [60] & Central- southern Italy (Molise) & $378 \mathrm{~km}^{2}$ & ca. 800 & 70 & $6.0 \%$ & 54 Informants \\
\hline$[61]$ & Eastern Italian Alps (Friuli- Venezia Giulia) & $5,700 \mathrm{~km}^{2}$ & ca. 3335 & 177 & $5.3 \%$ & n.d. Informants \\
\hline [53] & Western Italian Alps (Liguria) & $86 \mathrm{~km}^{2}$ & ca. 1500 & 105 & $7.0 \%$ & 65 Informants \\
\hline$[54]$ & Northern Italian Alps (Lombardy) & $896 \mathrm{~km}^{2}$ & ca. 2185 & 184 & $8.4 \%$ & 328 Informants \\
\hline Present study & Northern Italian Alps (South Tyrol) & $7,400 \mathrm{~km}^{2}$ & ca. 2169 & 275 & $12.0 \%$ & $\begin{array}{l}17 \text { Literature sources } \\
\text { (a.o. } 81 \text { informants in [31]) }\end{array}$ \\
\hline$[48]$ & North-west Spain (Basque Country) & $802 \mathrm{~km}^{2}$ & ca. 1133 & 139 & $12.3 \%$ & 207 Informants \\
\hline$[62]$ & Albanian Alps (Kosovo) & $3,500 \mathrm{~km}^{2}$ & ca. 1609 & 98 & $6.1 \%$ & 91 Informants \\
\hline$[63]$ & Eastern Switzerland (Prättigau) & $610 \mathrm{~km}^{2}$ & ca. 1414 & 204 & $14.4 \%$ & 91 Informants \\
\hline
\end{tabular}



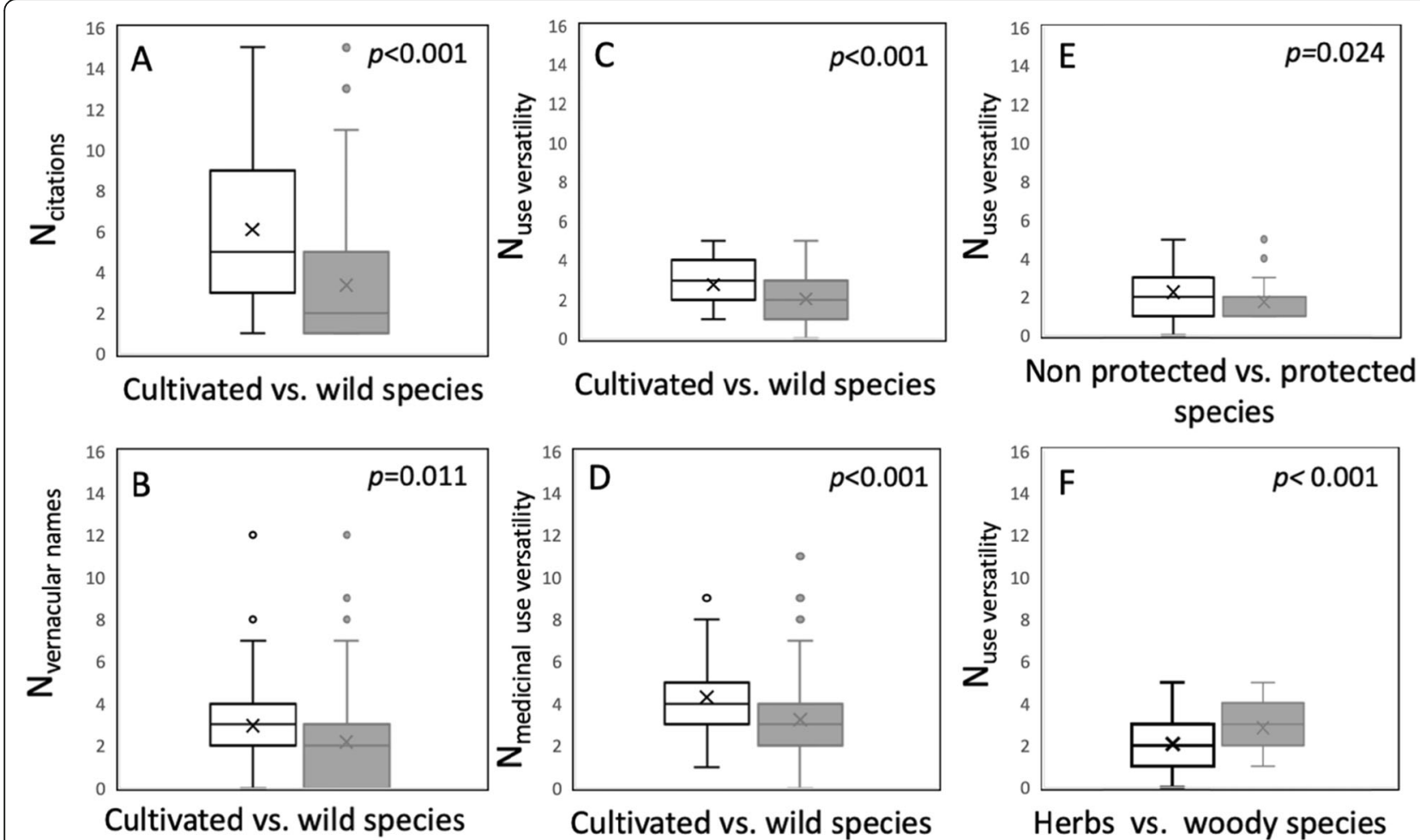

Fig. 5 Comparison of cultivated versus wild medicinal species regarding the a number of citations in folk medicinal literature, $\mathbf{b}$ number of vernacular names, c overall use versatility, and $\mathbf{d}$ medicinal use versatility in South Tyrol. Number of overall use versatility comparing non protected and (partially) protected species (e) and herbs versus woody species (shrubs and trees; $\mathbf{f}$ ). For results of the Kruskal-Wallis rank sum test, see text

cited plants probably also represent modern plants adapted by knowledge transfer, i.e., neighbors, books, and seminars. Thus, the list of plants with the most vernacular names may be the better scale for evaluating the traditional importance of a plant (Fig. 3 and Appendix B and C).

The high number of vernacular names per species (Appendix B) also illustrates the linguistic diversity of our study area, which is represented by the three official languages: German, Italian, and Ladin and manifold local dialects [66]. Overall, the findings from both indices reinforce the assumption that is highlighted in the ethnobotanical survey from [22], that traditional ethnobotanical knowledge is prevalent and well documented in the popular literature while the number of traditionally used species in the area is high.

Established herbal pharmacopoeias conserve local knowledge on medicinal species and function as profound repositories for buried knowledge that is currently assisting the revitalization of natural medicine. As a concequence, a variety of drugs that are derived from plants that were known to ancient civilizations and used throughout the millennia are today being included in modern pharmacotherapy [67].

Our analysis revealed that the use and subsequent abandonment of 17 species in South Tyrol is not linked to new pharmacological or phytochemical evidence on potential negative health effects or due to species conservation measures (protection or Red List status, Fig. 5). Moreover, there is limited scientific evidence on medicinal effects. Only $41 \%$ of the species, namely the most frequently cited species, have been explored by pharmacological studies in terms of their effects (Fig. 4).

Considering the most frequent families to which the medicinal plants belong (Asteraceae, Rosaceae, and Lamiaceae), our results were in high accordance with similar studies in European Alpine areas [3, 53-55]. The dominance of Asteraceae in local pharmacological literature worldwide has hitherto been emphasized (e.g., [68, $69])$. With regard to the most frequently quoted species, there was a general agreement between our results and other studies from Northern Italy. In particular, the species Achillea moschata, Achillea millefolium, Arnica montana, Urtica dioica, and Thymus pulegioides were highly valued throughout all regions [3, 53-55, 70]. Interestingly, the third most cited plant, Plantago lanceolata, was used only rarely or not at all in other northern Italian regions. Instead, the closely related $P$. major is used, which, while morphologically distinct, has similar medicinal properties $[3,55,70]$. Also, the two frequently cited plants, Equisetum arvense and Juniperus 
communis, appeared to be of minor importance in other northern Italian regions.

We observed a high overall use versatility in South Tyrol (Fig. 3). As was reported in other alpine areas [53, 54, 70], in South Tyrol the most frequent therapeutic uses, and the uses that accounted for the highest number of plants, were for digestive, respiratory, and integumentary systems (Table 3).

The majority (59\%) of native South Tyrolean medicinal plants remain understudied by medicine and pharmacology. However, considering the success rate $(>70 \%)$ of previously investigated plants (111) for which the traditional uses have been validated (79), we get an idea of the large unlocked phytotherapeutic and economic potential of as yet unexplored plants. In particular, the healing properties of the following largely unexplored plants should be analyzed, i.e., the highly quoted species Peucedanum ostruthium (wound healing, anti-inflammatory, digestive, and respiratory properties), Juniperus communis (antiseptic and for genitourinary problems), Alchemilla sp. and Achillea sp. (gynecology), Allium ursinum (cardiovascular, skin, digestion, and respiration), Campanula rotundifolia (borreliosis), Dryopteris filix-mas (antirheumatic and wound healing), Euphrasia sp. (antibacterial and antiinflammatory for eye and respiration), Geranium robertianum (genitourinary, wound healing and infertility), Larix decidua (wound healing and disinfectant), Pinus mugo (expectorant), Sempervivum tectorum (wound healing), Stachys sylvatica (wound-healing and digestion), and Veronica officinalis (respiration, digestion, and musculoskeletal). A few almost exclusive uses were also found in the study area that, to our knowledge, have not been documented before in other Alpine areas. An example of an undocumented plant is of the Geranium robertianum, the flower and leaves of which are used in a tea to help with fertility issues [71]. Another is the use of Botrychium lunaria as an abortifacient [72].

Our results revealed a strong association between food and medicinal uses of the plants, including 128 aromatic or food related species $(46.5 \%$ of all mentioned species) from over 50 families (Table 1). The most beneficial effects were on digestive, respiratory, skin, and general and unspecific disorders (Table 3). In fact, considering the increasing importance attributed to nutrition on human health maintenance, both therapeutic or prophylactic $[73,74]$, these plants could be of high relevance for the development of nutraceuticals [20]. This may be of particular interest to local sustainability projects that focus on local foods, eco-gastronomy, and organic farming. Examples include juice made from Sambucus nigra berries with antiviral and antimicrobial effects [75, 76], jam made out of Rosa canina fruits as a supplement of vitamin C [77], or Thymus sp. as spice with antibacterial effects [78]. Further research is needed to determine the nutritional and chemical compounds as well as safety for the commercialization of these exceptional food sources.

\section{Traditional medicinal plants for the conservation of nature and cultural heritage}

For some years, there has been an emerging interest in the use of traditional ethnobotanical knowledge and plant resources [64]. While in the past, medicinal plants were mainly used for home consumption, the cultivation and use of medicinal plants has become a growing market niche in South Tyrol in the last few decades [51]. We recorded at least 21 farms where the main income source was herb production [79], and several gastronomy and hotel businesses that offered seasonal dishes or wellness and recreation programs based on traditional plants and practices [80]. In fact, the commercial use of herbal plants seems to offer numerous positive effects for the economic and ecological sustainability of South Tyrol, i.e., (i) the diversification of agricultural production, (ii) the maintenance of rural economies, (iii) the establishment of local value chains, (iv) the preservation of traditional land-use types (e.g., larch meadows or semiarid grasslands; [81]) through extensive and ecologically oriented farming systems, (v) the maintenance of an important source of food supply for insects, and (vi) the preservation and revitalization of local identities, with a likely positive effect on biodiversity conservation.

Considering the positive market prospects for herbal products, with annual growth rates between 8 and 15\% in Europe, North America, and Asia [82], traditional knowledge and plant resources offer a support for local economies. In this context, the various edible and medicinal plants identified in this study could provide opportunities for further diversification of mountain agriculture. Nevertheless, traditional medicinal plants still lack recognition as an economic factor in South Tyrol. Therefore, further research on agro-ecology, nutrition, bioactivity, and safety are highly important for the commercialization of tradition medicinal plants [21].

Many medicinal plants in the study area were threatened by anthropogenic and natural factors. Our analysis showed that 238 of the medicinal plant species $(86 \%)$ were abundant, whereas 24 species (9\%) were very rare and placed under the category of "conservation concern" on the regional Red List [29] (Table 2). Land-use changes, overexploitation, and climate change are considered to be the most serious threats to medicinal plants in Alpine regions [2, 19, 64]. Biodiversity in the Alps is closely linked to the interaction between the natural environment and traditional human practices [33]. The changes in social, touristic, and agricultural systems in the last 
decades led to a substantial conversion of land-use systems. This includes the intensification of land use in easily accessible areas [83] as well as the abandonment of traditional practices in remote areas that results in a decrease of species diversity and abundance $[81,84]$. Consequently, along with the decrease in biodiversity, the abundance of medicinal plants is also affected [6]. In South Tyrol, the abandonment of alpine meadows and pastures along with the related expansion of areas of shrubs and trees has led to a decline of several heliophilous grassland species such as Arnica montana and Centaurium erythraea [85]. Moreover, many medicinal plants (e.g., Carlina acaulis, Gentiana acaulis, Anemone vernalis) that flourish in poor soils have been affected by increased nutrient input caused by fertilization [81].

Unsustainable exploitation of wild collected species is a well-known effect of booming markets with rising demands [64]. In addition, for South Tyrol, an increasing pressure on wild species has been reported by $\mathrm{T}$. Wilhalm (pers. comm., Sept. 24, 2019). However, a closer look at the life forms and plant parts harvested reveals that not all species are equally affected by collection pressure. Root harvesting as a common practice in South Tyrol can be a severe threat to some rare medicinal plant species. Among root-harvested plants, we identified 6 particularly endangered species, three of which are under protection, two that are unprotected (Dipsacus fullonum and Althaea officinalis), and one species (Eryngium campestre) that is already extinct (Table 2). These threatened but unprotected plants should be re-considered and introduced into the South Tyrolean legislation.

Global warming and the associated upward migration of vegetation has become a major threat to specialized Alpine plants, particular those that inhabit the alpine-nivale altitudinal zones ( $>2600 \mathrm{~m}$ a.s.l.) $[22,86]$. Based on the GLORIA project data set, [22] concluded that for South Tyrol, with its highest peaks at almost $4000 \mathrm{~m}$ a.s.l., most plants can continue to invade higher elevations and, thus, the risk of extinction seems to be low. However, [22] identified two species (Artemisia genipi and Primula glutinosa) that are restricted to the upper Alpine zone and therefore might not be able to migrate further upward. Based on the same methodology, but with a larger data set, we identified at least 10 additional medicinal plant species that are restricted to the upper Alpine zone and therefore might be endangered by warming, at least locally (Table 4). In the foreseeable future, this could be the case in the Sella/Latemar region, for example, or the Texel group where the highest summits do not exceed $3200 \mathrm{~m}$ and the elevation distance between upper alpine and highest summit is less than
$600 \mathrm{~m}$ a.s.l. On the other hand, however, some endangered medicinal plants such as the thermophilous species Marrubium vulgare may also benefit from warming.

\section{Conclusion}

This study recorded the use of 275 traditional medicinal plants in South Tyrol. The values of EPI and EI show that ethnobotanical knowledge and plant diversity in the area were among the highest in Italy and the European Alps. Our results show a loss of local traditional knowledge and plants in the region, where over 85 of medicinal plants are listed in the regional Red List. On the other hand, the renewed interest in natural medicine has transformed the use of traditional medicinal plants into a new market niche for mountain agriculture in South Tyrol. Vulnerable but unprotected plant species should be reconsidered and introduced into the South Tyrolean legislation or addressed by ecosystem restoration measures. Furthermore, several plant species that are highly valued in local folk medicine remain understudied within medicine and pharmacology and could thus provide a starting point for further studies that may lead to the discovery of new molecules and opportunities for the diversification of mountain agriculture. The conservation and cultivation of traditional medicinal plants as well as the conservation and restoration of their habitats could provide new services for society and for land use and thus contribute to the population's wellbeing and ecologically sustainable development.

\section{Supplementary information}

Supplementary information accompanies this paper at https://doi.org/10. 1186/s13002-020-00419-8.

Additional file 1. Appendix A.

Additional file 2. Appendix $B$.

Additional file 3. Appendix $C$.

\section{Acknowledgements}

We would like to thank three anonymous reviewers for their helpful comments and suggestions on a previous version of this manuscript. We are grateful to Thomas Wilhalm of the Nature Museum South Tyrol (Bolzano, N Italy). We thank Sylvia Butenschön (Technical University Berlin) for providing the photos in Fig. 1 and Owen Lyons for improving the English.

\section{Cytography}

http://www.theplantlist.org/.

\section{Authors' contributions}

JP designed the study, performed a literature review on ethnobotany (and other areas), and contributed to the writing of the manuscript and drawing of graphics. BP designed the study and contributed to the writing of the manuscript. IS designed the study and contributed to the writing of the manuscript and drawing of graphics. SZ designed the study and contributed to the writing of the manuscript and drawing of graphics. All authors read and approved the final manuscript. 


\section{Funding}

This research was performed within the Transdisciplinary Environment \& Health Research Network (TER), funded by the Autonomous Province of South Tyrol. We acknowledge support by the German Research Foundation (DFG) and the Open Access Publication Fund of Humboldt-Universität zu Berlin. Open Access funding enabled and organized by Projekt DEAL.

\section{Availability of data and materials}

The datasets used and/or analyzed during the current study are available in the appendices of the study. Further information is available from the corresponding author on reasonable request.

\section{Ethics approval and consent to participate}

All participants were asked for their free prior informed consent before interviews were conducted.

\section{Consent for publication}

Not applicable.

\section{Competing interests}

The authors declare that they have no competing interests.

\section{Author details}

${ }^{1}$ Faculty of Science and Technology, Free University of Bozen-Bolzano, Bolzano, Italy. ${ }^{2}$ Faculty of Education, Free University of Bozen-Bolzano, Bolzano, Italy. ${ }^{3}$ Institute of General Medicine, College of Health Care Professions Claudiana, Bozen, Italy. ${ }^{4}$ Integrative Research Institute on Transformations of Human-Environment Systems (IRITHESys), Humboldt Universität zu Berlin, Berlin, Germany.

\section{Received: 15 June 2020 Accepted: 8 October 2020}

Published online: 26 November 2020

\section{References}

1. Bussmann RW. Ethnobotany of the Samburu of Mt. Nyiru, South Turkana, Kenya. J Ethnobiol Ethnomed. 2006;2(35).

2. Salick J, Zhendong F, Byg A. Eastern Himalayan alpine plant ecology, Tibetan ethnobotany, and climate change. Glob Environ Chang. 2009;19: 147-55.

3. Vitalini S, Iriti M, Puricelli C, et al. Traditional knowledge on medicinal and food plants used in Val san Giacomo (Sondrio, Italy) - an alpine ethnobotanical study. J Ethnopharmacol. 2013;145:517-29.

4. Joshi AR, Joshi K. Indigenous knowledge and uses of medicinal plants by local communities of the Kali Gandaki watershed area, Nepal. J Ethnopharmacol. 2000;73:175-83.

5. Patwardhan B. Ethnopharmacology and drug discovery. J Ethnopharmacol. 2005:100:50-2

6. Neergheen-Bhujun V, Awan AT, Baran Y, et al. Biodiversity, drug discovery, and the future of global health: introducing the biodiversity to biomedicine consortium, a call to action. J Glob Health. 2017;7:020304.

7. Chapin FS, Zavaleta ES, Eviner VT, et al. Consequences of changing biodiversity. Nature. 2000:405:234-42.

8. Butchart SHM, Walpole M, Collen B, et al. Global biodiversity: indicators of recent declines. Science. 2010:328:1164-8.

9. Thomas $C D$, Cameron A, Green RE, et al. Extinction risk from climate change. Nature. 2004;427:145-8.

10. Vittoz $P$, Cherix D, Gonseth $Y$, et al. Climate change impacts on biodiversity in Switzerland: a review. J Nat Conserv. 2013;21:154-62.

11. Pertoldi C, Bach LA. Evolutionary aspects of climate-induced changes and the need for multidisciplinarity. J Therm Biol. 2007:32:118-24.

12. Pimm SL, Jenkins $C N$, Abell $R$, et al. The biodiversity of species and their rates of extinction, distribution, and protection. Science. 2014;12467521246752:344.

13. Sen T, Samanta SK. Medicinal plants, human health and biodiversity: a broad review. Adv Biochem Eng Biotechnol. 2014;147:59-110.

14. UNCED. Convention on biological diversity. Sharm El-Sheikh, Egypt: United Nations Commission on Environment and Development; 2018.

15. UNESCO. The universal declaration on cultural diversity. United Nations Educational, Scientific and Cultural Organization, Paris. France. 2002:11:129-36.

16. Berkes F. Sacred ecology: Routledge; 2017.
17. Niedrist G, Tasser E, Lüth C, et al. Plant diversity declines with recent land use changes in European Alps. Plant Ecol. 2009;202:195-210.

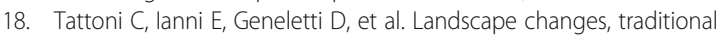
ecological knowledge and future scenarios in the Alps: a holistic ecological approach. Sci Total Environ. 2017;579:27-36.

19. Pieroni A, Giusti ME. Alpine ethnobotany in Italy: traditional knowledge of gastronomic and medicinal plants among the Occitans of the upper Varaita valley. Piedmont J Ethnobiol Ethnomed. 2009;5:1-13.

20. Abbet C, Mayor R, Roguet D, et al. Ethnobotanical survey on wild alpine food plants in lower and Central Valais (Switzerland). J Ethnopharmacol. 2014;151:624-34.

21. Pinela J, Carvalho AM, Ferreira ICFR. Wild edible plants: nutritional and toxicological characteristics, retrieval strategies and importance for today's society. Food Chem Toxicol. 2017;110:165-88.

22. Grabherr G. Biodiversity in the high ranges of the Alps: ethnobotanical and climate change perspectives. Glob Environ Chang. 2009;19:167-72.

23. Pleszczyńska M, Lemieszek MK, Siwulski M, et al. Fomitopsis betulina (formerly Piptoporus betulinus): the Iceman's polypore fungus with modern biotechnological potential. World J Microbiol Biotechnol. 2017;33.

24. European Soil Data Centre (ESDAC). European Commission. In: Joint Research Centre; 2012

25. ASTAT. Statistisches Jahrbuch Für Südtirol 2018Autonome Provinz Bozen/ Südtirol Landesinstitut Für Statistik - ASTAT: 2018.

26. Karte PT, Südtirols DAV. Autonome Provinz Bozen-Südtirol - Amt für Naturparke. Wien: Naturschutz Und Landscaftspflege; 1991.

27. Oeschger H, Messerli B, Svilar M. Das Klima von Tirol - Südtirol - Belluno; 1980.

28. Wilhalm T, Gutermann W, Niklfeld H. Katalog Der Gefässpflanzen Südtirols. Auflage: 1. Folio: Wien; 2006

29. Wilhalm T. Hilpold. Rote Liste der gefährdeten Gefäßpflanzen Südtirols. Gredleriana. 2006:115-98.

30. Zinn DL. Migrants as metaphor. CISU: Institutions and Integration in South Tyrol's Divided Society. Roma; 2018.

31. Pickl-Herk W. Volksmedizinische Anwendung von Arzneipflanzen im Norden Südtirols. Unpubl Diploma Thesis Univ Wien. 1995;295.

32. Eichinger L. South Tyrol: German and italian in a changing world. J Multiling Multicult Dev. 2002;23:137-49.

33. Chemini C, Rizzoli A. Land use change and biodiversity conservation in the Alps. J Mt Ecol. 2003;7:1-7.

34. Shamseer $L$, Moher D, Clarke $M$, et al. Preferred reporting items for systematic review and meta-analysis protocols (prisma-p) 2015: elaboration and explanation. BMJ. 2015:349.

35. Mayer $M$, Zbinden $M$, Vogl CR, et al. Swiss ethnoveterinary knowledge on medicinal plants - a within-country comparison of Italian speaking regions with north-western German speaking regions. J Ethnobiol Ethnomed. 2017;13:1.

36. Stucki $\mathrm{K}$, Cero MD, Vogl CR, et al. Ethnoveterinary contemporary knowledge of farmers in pre-alpine and alpine regions of the Swiss cantons of Bern and Lucerne compared to ancient and recent literature - is there a tradition? J Ethnopharmacol. 2019;234:225-44.

37. Owen DJ, Fang M-LE. Information-seeking behavior in complementary and alternative medicine (CAM): an online survey of faculty at a health sciences campus. J Med Libr Assoc. 2003;91:311-21.

38. Südtirol N. FloraFaunaSüdtirol. Das Portal zur Verbreitung von Tier- und Pflanzenarten in Südtirol. 2019

39. Nimis PL, Martellos S. ITALIC 5.0 - the information system on Italian lichens. In: Version 5, vol. 0. Dept. of Biology: University of Trieste; 2017.

40. Curti PAMINT. Associazione Micologica Italiana Naturalistica. Telematica. 2019.

41. The Plant List. Version 1.1. In: Published on the internet; 2013

42. Cunningham AB. Applied ethnobotany : people, wild plant use, and conservation: Earthscan; 2001.

43. Berlin B. Ethnobiological classification : principles of categorization of plants and animals in traditional societies: Princeton University Press; 1992

44. ICPC-2. International Classification of Primary Care second ed.

45. Staub PO, Geck MS, Weckerle CS, et al. Classifying diseases and remedies in ethnomedicine and ethnopharmacology. J Ethnopharmacol. 2015;174:514-9.

46. Bundesinstitut für Arzneimittel und Medizinprodukte. Liste der Monographien der Kommission E (Phytotherapie). In: Die im Bundesanzeiger veröffentlicht Sind; 2002.

47. European Union monographs and list entries | European Medicines Agency. 
48. Menendez-Baceta G, Aceituno-Mata L, Molina M, et al. Medicinal plants traditionally used in the northwest of the Basque Country (Biscay and Alava), Iberian Peninsula. J Ethnopharmacol. 2014;152:113-34.

49. Portères R. Ethnobotanique Générale. Paris: Laboratoire d'Ethnobotanique et Ethnozoologie; 1970.

50. Bonet MÀ, Parada M, Selga A, et al. Studies on pharmaceutical ethnobotany in the regions of L'Alt Empordà and les Guilleries (Catalonia, Iberian Peninsula). J Ethnopharmacol. 1999;68:145-68.

51. Schunko C, Lechthaler S, Vogl CR. Conceptualising the factors that influence the commercialisation of non-timber forest products: the case of wild plant gathering by organic herb farmers in South Tyrol (Italy). Sustainability. 2019;11.

52. Fischer MA, Gottschlich G. Exkursionsflora Für Österreich, Liechtenstein Und Südtirol Bestimmungsbuch Für Alle in Der Republik Österreich, in Der Autonomen Provinz Bozen/Südtirol (Italien) Und Im Fürstentum Liechtenstein Wildwachsenden Gefäßpflanzen (Farnpflanzen und Samenp. OÖ) Landesmuseen, 2005.

53. Cornara L, La Rocca A, Terrizzano L, et al. Ethnobotanical and phytomedical knowledge in the North-Western Ligurian Alps. J Ethnopharmacol. 2014;155: 463-84.

54. Vitalini S, Puricelli C, Mikerezi I, et al. Plants, people and traditions: Ethnobotanical survey in the Lombard Stelvio National Park and neighbouring areas (Central Alps, Italy). J Ethnopharmacol. 2015;173:435-58.

55. Dei Cas L, Pugni F, Fico G. Tradition of use on medicinal species in Valfurva (Sondrio, Italy). J Ethnopharmacol. 2015;163:113-34.

56. Tali BA, Khuroo AA, Nawchoo IA, et al. Prioritizing conservation of medicinal flora in the Himalayan biodiversity hotspot: an integrated ecological and socioeconomic approach. Environ Conserv. 2019;46:147-54.

57. Assefa A, Bahiru A. Ethnoveterinary botanical survey of medicinal plants in Abergelle, Sekota and Lalibela districts of Amhara region, northern Ethiopia. J Ethnopharmacol. 2018;213:340-9.

58. Gao L, Wei N, Yang G, et al. Ethnomedicine study on traditional medicinal plants in the Wuliang Mountains of Jingdong, Yunnan, China. J Ethnobiol Ethnomed. 2019;15.

59. Ferrier J, Saciragic L, Trakić S, et al. An ethnobotany of the Lukomir highlanders of Bosnia \& Herzegovina. J Ethnobiol Ethnomed. 2015;11.

60. Guarrera P, Lucchese F, Medori S. Ethnophytotherapeutical research in the high Molise region (central-southern Italy). J Ethnobiol Ethnomed. 2008;4:1-11.

61. Lokar LC, Poldini L. Herbal remedies in the traditional medicine of the Venezia Giulia region (north East Italy). J Ethnopharmacol. 1988;22:231-79.

62. Mustafa B, Hajdari A, Krasniqi F, et al. Medical ethnobotany of the Albanian Alps in Kosovo. J Ethnobiol Ethnomed. 2012;8:1-14.

63. Wegmann U. Ethnobotanik im Prättigau. Medizinalpflanzen - Nutzung und Wissen. Master-Thesis, Univ Zürich, Switzerland 2013.

64. Schippmann U, Leaman DJ, Cunningham AB. Impact of cultivation and gathering of medicinal plants on biodiversity: global trends and issues. Rome, Italy: Inter-Department Work Gr Biol Divers Food Agric FAO; 2002

65. Guarrera PM, Lucia LM. Ethnobotanical remarks on central and southern Italy, vol. 3; 2007. 23.

66. Meraner R, Oberhofer M. Dialekte und Hochsprache in der Schule; Arbeitskreis Südtiroler Mittelschullehrer. Hrsg. Von Kurt Egger, Bozen, 1982. 1982.

67. Petrovska BB. Historical review of medicinal plants' usage. Pharmacogn Rev. 2012;6:1-5.

68. Heinrich M, Robles M, West JE, et al. Ethnopharmacology of Mexican Asteraceae (Compositae). Annu Rev Pharmacol Toxicol. 1998;38:539-65.

69. Saslis-Lagoudakis CH, Williamson EM, Savolainen V, et al. Cross-cultural comparison of three medicinal floras and implications for bioprospecting strategies. J Ethnopharmacol. 2011;135:476-87.

70. Vitalini S, Tomè F, Fico G. Traditional uses of medicinal plants in Valvestino (Italy). J Ethnopharmacol. 2009;121:106-16.

71. Hochgruber G. Heilkräuter - Die Apotheke der Natur Alternative Heilmethoden Nach Gottfried Hochgruber., 2018.

72. Achmüller A. Teufelskraut, Bauchwehblüml, Wurmtod: Das Kräuterwissen Südtirols: Mythologie, Volksmedizin und Wissenschaftliche Erkenntnisse. Edition Raetia, 2012.

73. Etkin NL. Medicinal cuisines: diet and ethopharmacology. Int J Pharmacogn. 1996;34:313-26

74. Tapsell LC, Neale EP, Satija A, et al. Foods, nutrients, and dietary patterns: interconnections and implications for dietary guidelines. Adv Nutr. 2016;7: 445-54.
75. Chen C, Zuckerman DM, Brantley S, et al. Sambucus nigra extracts inhibit infectious bronchitis virus at an early point during replication. BMC Vet Res. 2014;10:24.

76. Krawitz C, Mraheil MA, Stein M, et al. Inhibitory activity of a standardized elderberry liquid extract against clinically-relevant human respiratory bacterial pathogens and influenza a and B viruses. BMC Complement Altern Med. 2011;11:16.

77. Mihoc M, Mihai C. Ascorbic acid content in extractive aqueous solutions of Rosa canina L. Fruits Agric Conspec Sci. 2008;73:19-22.

78. Rasooli I, Mirmostafa SA. Antibacterial properties of Thymus pubescens and Thymus serpyllum essential oils. Fitoterapia. 2002;73:244-50.

79. Vereinigung Südtiroler Kräuteranbauer.

80. Karnutsch V. Innovation und bäuerliche tradition am Beispiel der Südtiroler Heubäder. Diploma Thesis, Free Univ Bolzano. 2004;126.

81. Zerbe S. Renaturierung von Ökosystemen Im Spannungsfeld von Mensch und Umwelt: Ein Interdisziplinäres Fachbuch. SPRINGER, 2019.

82. Verma S, Singh S. Current and future status of herbal medicines. Vet World. 2008;2:347.

83. Grabherr G. Biodiversitätsverlust durch moderne Hochlagen-Landwirtschaft. Jahrb des Vereins zum Schutz der Bergwelt. 2010;74-75:29-40.

84. Tasser $E$, Tappeiner $U$, löschen $S$, et al. Impact of land use changes on mountain vegetation. Appl Veg Sci. 2002:5:173-84.

85. Michler B, Rotar I, Pacurar F et al. Arnica montana, an endangered species and a traditional medicinal plant: the biodiversity and productivity of its typical grasslands habitats. Integrating Efficient Grassland Farming and Biodiversity. Vol 10. Proceedings of EGF, Estonia, 2005, 336-40.

86. Chelli S, Wellstein C, Campetella G, et al. Climate change response of vegetation across climatic zones in Italy. Clim Res. 2017;71:249-62.

\section{Publisher's Note}

Springer Nature remains neutral with regard to jurisdictional claims in published maps and institutional affiliations.

Ready to submit your research? Choose BMC and benefit from

- fast, convenient online submission

- thorough peer review by experienced researchers in your field

- rapid publication on acceptance

- support for research data, including large and complex data types

- gold Open Access which fosters wider collaboration and increased citations

- maximum visibility for your research: over $100 \mathrm{M}$ website views per year

At BMC, research is always in progress.

Learn more biomedcentral.com/submissions 